\title{
Coagulation disorders and thromboembolic disease in COVID-19: review of current evidence in search of a better approach
}

\author{
Alberto García-Ortega ${ }^{1,2}$, David de la Rosa ${ }^{3}$, Grace Oscullo ${ }^{1,2}$, Diego Castillo-Villegas ${ }^{3}$, \\ Raquel López-Reyes ${ }^{1}$, Miguel Ángel Martínez-García ${ }^{1}$
}

${ }^{1}$ Pneumology Department, Hospital Universitario and Politécnico La Fe, 46026 Valencia, Spain; ${ }^{2}$ Medical Research Institute Hospital La Fe (IISLAFE), 46026 Valencia, Spain; ${ }^{3}$ Pneumology Department, Hospital Universitario Santa Creu i Sant Pau, 08041 Barcelona, Spain

Contributions: (I) Conception and design: A García-Ortega, MA Martínez-García; (II) Administrative support: MÁ Martínez-García; (III) Provision of study materials or patients: All authors; (IV) Collection and assembly of data: A García-Ortega, R López-Reyes, G Oscullo; (V) Data analysis and interpretation: All authors; (VI) Manuscript writing: All authors; (VII) Final approval of manuscript: All authors.

Correspondence to: Alberto García-Ortega. Respiratory Department, Hospital Universitario and Politécnico La Fe, Avenida Fernando Abril Martorell 106, 46026 Valencia, Spain. Email: albortgva@gmail.com.

\begin{abstract}
The new severe acute respiratory syndrome coronavirus 2 (SARS-CoV-2) has been an unprecedented global health problem, causing more than 20 million infections and more than 900,000 deaths (September 2020). The SARS-CoV-2 infection, known as COVID-19, has various clinical presentations, from asymptomatic or mild catarrhal processes to severe pneumonia that rapidly progresses to acute respiratory distress syndrome (ARDS) and multiple organ failure. In the last few months, much scientific literature has been devoted to descriptions of different aspects of the coagulation disorders and arterial and venous thrombotic complications associated with COVID-19, particularly venous thromboembolism (VTE). These studies have revealed that SARS-CoV-2 could lead to a prothrombotic state reflecting the high cumulative incidence of associated thrombotic events, particularly in patients admitted to intensive care units (ICUs). As regards the coagulopathy observed in association with SARS-CoV-2 infection, the mechanisms that activate coagulation have been hypothesized as being linked to immune responses, through the release of pro-inflammatory mediators that interact with platelets, stimulate the expression of tissue factor, induce an upregulation of plasminogen activator inhibitor-1, suppress the fibrinolytic system and lead to endothelial dysfunction, triggering thrombogenesis. D-dimer elevation has been recognized as a useful biomarker of poor prognosis, although the best cut-off point for predicting VTE in COVID-19 patients has still not been clarified. This review will try to update all the available scientific information on this important topic with enormous clinical and therapeutic implications.
\end{abstract}

Keywords: Pulmonary embolism (PE); coronavirus disease 2019 (COVID-19); D-dimer; thrombosis; inflammation

Submitted Sep 24, 2020. Accepted for publication Dec 18, 2020.

doi: $10.21037 /$ jtd-20-3062

View this article at: http://dx.doi.org/10.21037/jtd-20-3062

\section{Introduction}

In December 2019, the Chinese authorities reported atypical pneumonia clusters of unknown etiology in Wuhan. On 7 January 2020, a novel coronavirus from the Coronaviridae family, the new severe acute respiratory syndrome coronavirus 2 (SARS-CoV-2), was confirmed as being responsible for the outbreak of these respiratory infections and then named coronavirus disease 2019 (COVID-19) (1-3).

COVID-19 has been an unprecedented global health problem, causing more than 25 million infections and more than 900,000 deaths [Centres for Disease Control and Prevention (CDC), World Health Organization 
(WHO); September 2020]. SARS-CoV-2 seems to enter cells by endocytosis, through the binding of virus envelope glycoprotein to the angiotensin-converting enzyme-2 receptor found in the cells of upper airways, lungs, heart and gastrointestinal tract, as well as in the blood vessels (4). SARS-CoV-2 infection has various clinical presentations, from asymptomatic or mild catarrhal processes to severe pneumonia that rapidly progresses to acute respiratory distress syndrome (ARDS) and multiple organ failure (1). Preliminary reports have suggested that COVID-19 infection can produce coagulation disorders, mainly in more severe forms of presentation, and predispose to thrombotic events and both arterial and venous thrombosis (2,3,5-10). Furthermore, COVID-19 has commonly been associated with coagulopathy in most of the deceased patients. The data derived from all these publications on COVID-19associated coagulopathy and thrombotic risk have generated doubts and controversy about the best strategy for the thromboprophylaxis, diagnosis and anticoagulant therapy of venous thromboembolism (VTE), as reflected in the variability of the recommendations published by different expert groups.

Therefore, this manuscript summarizes the current published literature regarding the key aspects of coagulation disorders and VTE risk in COVID-19, mainly focusing on pulmonary embolism (PE), and it addresses clinical issues in order to improve our approach to the prophylaxis, diagnosis and management of VTE in COVID-19 patients. We present the following article/case in accordance with the PRISMA reporting checklist (available at http://dx.doi. org/10.21037/jtd-20-3062).

\section{Coagulation disorders associated with COVID-19}

Various studies have suggested that SARS-CoV-2 induces coagulation disorders, which are associated with poorer outcomes. The most common pattern of coagulopathy is characterized by increased levels of fibrinogen and D-dimer, a slight rise in the prothrombin time (PT) and the activated partial thromboplastin time (aPTT), and a mild thrombocytopenia (2-9,11-14). Of all these factors, the D-dimer is the one most consistently associated with COVID-19. The very first series of hospitalized patients in China already presented elevated levels of D-dimer $(\geq 0.5 \mathrm{mg} / \mathrm{L})$ in $46 \%$ of the cases (2). One study has shown that COVID-19 patients present elevated levels of D-dimer, significantly higher than those found in healthy controls (15). Even more importantly, early studies identified a greater frequency of elevated D-dimer in patients with more severe forms of presentation of COVID-19 (60\% vs. $43 \% ; \mathrm{P}=0.002)(2,15,16)$. Moreover, a comparison of the $\mathrm{D}$-dimer values at admission of the more severely ill patients who would require treatment in an intensive care unit (ICU) and those of the remaining COVID-19 patients confirmed that these values were higher in the former case $(3,4)$. Along the same lines, Tang et al. found a relationship between mortality from COVID-19 and D-dimer values in a retrospective study, with these values being almost 3.5 times higher in deceased patients $(2.1$ vs. $0.6 \mathrm{mg} / \mathrm{L}$; $\mathrm{P}=0.001$ ) (7). Similarly, Zhou et al. published the data from a retrospective series of 191 patients hospitalized for COVID-19 in Wuhan (137 survivors, 54 non-survivors) and also found higher $\mathrm{D}$-dimer values on admission in the group of deceased patients than in that of the survivors (5.2 vs. $0.6 \mathrm{mg} / \mathrm{L} ; \mathrm{P}<0.001$ ), with a cut-off point of $1.0 \mathrm{mg} / \mathrm{L}$ an independent risk factor for mortality [multivariable analysis presented odds ratio (OR) 18.4; 95\% confidence interval (CI): 2.6-128.6; $\mathrm{P}=0.0033$ ] (8). A meta-analysis of 553 COVID-19 patients (22\% admitted to the ICU) established a D-dimer cut-off point of $3.0 \mathrm{mg} / \mathrm{L}$ to identify severely ill patients (9). This correlation between the severity of the disease and the $\mathrm{D}$-dimer values was also reported in another meta-analysis that found significantly higher D-dimer values in patients with ARDS compared to non-ARDS patients $(\mathrm{P}<0.001)$; moreover, within the group of ARDS patients itself, those who died presented higher D-dimer values than the survivors $(\mathrm{P}<0.001)(16)$.

Another significant marker of coagulation related to the prognosis is the PT. Higher PT values have been associated with both the need for ICU management and greater mortality $(3,7,8)$.

In short, COVID-19 patients present coagulation disorders that are mainly defined by an elevated D-dimer, and this finding has proved to be associated with more severe forms of presentation, including ARDS and the need for an ICU, as well as a higher mortality rate.

\section{Pathophysiology of COVID-19-associated coagulopathy}

Both the relationship between inflammation and haemostasis and the activation of the coagulation cascade in infections are well known, and basically explained by the pathophysiology of the immune-thrombotic response in situations involving sepsis (Figure 1) (17). Sepsis is thus characterized by a pro-coagulant, pro-inflammatory and 


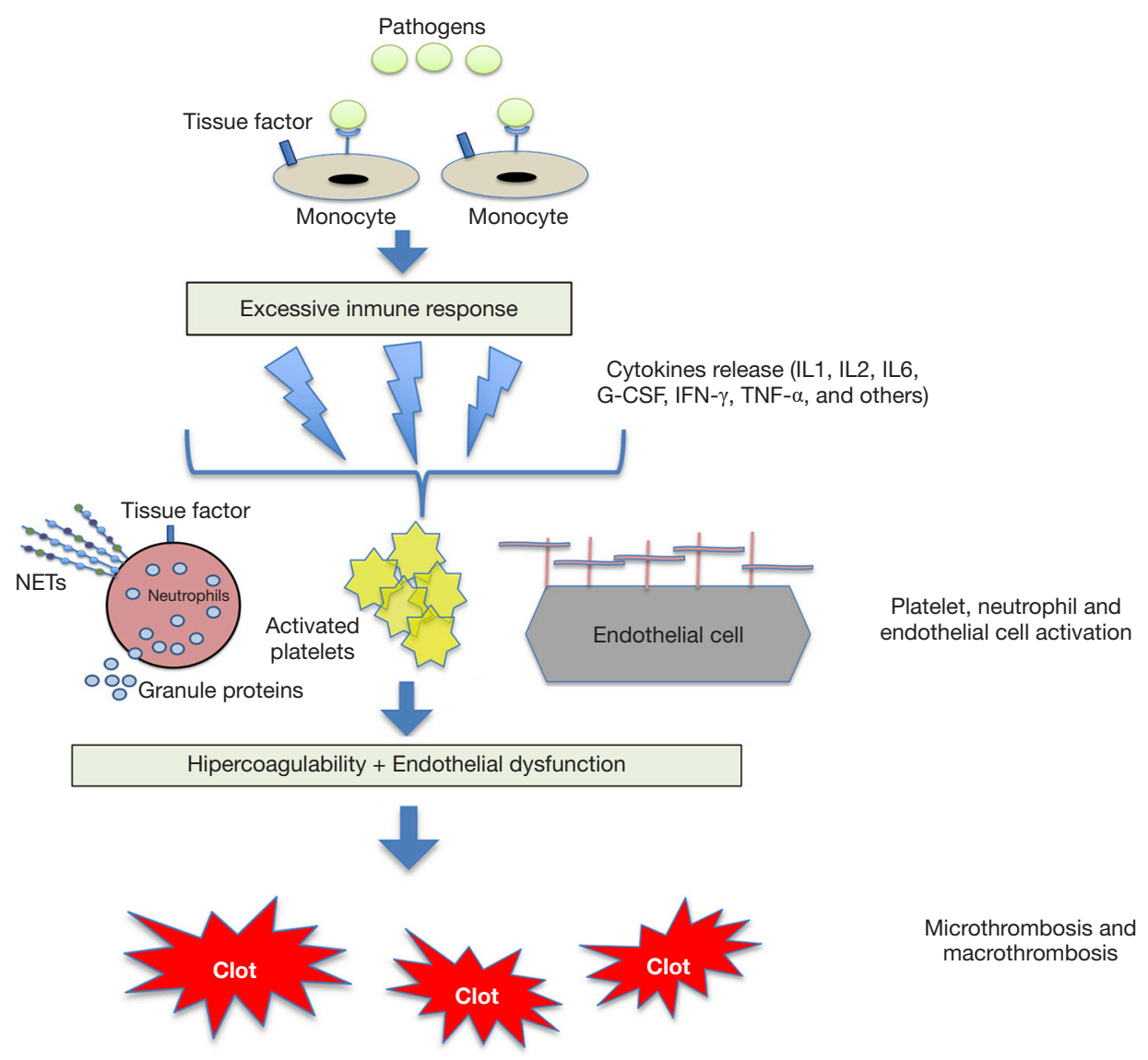

Figure 1 Pathophysiology of coagulation activation in sepsis. The pathogens and its components stimulate the monocytes via specific receptors situated on the surface of their cells. The activated monocytes produce a hyperimmune response with the release of various cytokines and other inflammatory mediators that activate platelets, neutrophils and endothelial cells. A state of hypercoagulability and endothelial damage that modifies the properties of the endothelium from an anticoagulant to a procoagulant state through the interruption of the glycocalyx and the expression of the von Willebrand factor (VWF). Neutrophils, in their turn, express tissue factor and release granulated proteins and other procoagulant mediators, such as neutrophil extracellular traps (NETs) comprised of procoagulant DNA, histones and other molecular patterns associated with cellular damage. All the above leads to the development of micro- and macrothrombotic phenomena. Adapted from ref (17) [with permission of Sociedad Española de Neumología y Cirugía Torácica (SEPAR) copyright]. G-CSF, granulocyte colony-stimulating factor; TNF, tumor necrosis factor; IFN, interferon; IL, interleukin; NETs, neutrophil extracellular traps.

anti-fibrinolytic state that involves many cell strains (such as monocytes, macrophages, neutrophils and the vascular endothelium). Pathogens bind to specific receptors of cells with innate immunity, triggering the release of various cytokines and other inflammatory biomarkers. Cytokines such as IL-6 and IL-8 act by activating the platelets and modifying the properties of the endothelium from an anti-coagulant to a pro-coagulant state by interrupting the glycocalyx and activating clotting factors (e.g., von Willebrand factor). Furthermore, the neutrophils express tissue factor, trigger and initiate coagulative extrinsic cascades and release thrombotic mediators [e.g., neutrophil extracellular traps (NETs)] that enhance platelet activation (18-23).

The indiscriminate activation of this pathophysiological mechanism gives rise to the picture known as disseminated intravascular coagulation (DIC), which is characterized by the presence of thrombocytopenia, the consumption of coagulation factors and high levels of fibrin degradation products like D-dimer (18-20). 
The mechanisms that activate coagulation in COVID-19 have not been fully clarified but they appear to be more closely related to the inflammatory response than the specific virulent properties of the germen (11). It has been shown, for example, that patients with severe SARS-CoV-2 infection present an excessive inflammatory response, with lymphopenia and high levels of ferritin, D-dimer and various cytokines $(11,12)$. In fact, interleukin (IL)-6 plays a fundamental role in the activation of the extrinsic coagulation route (18). Accordingly, it has been postulated that this hyper-inflammatory response in COVID-19 patients, known as a cytokine storm, activates the coagulation cascade. The vascular endothelium seems to play a crucial role in this pathophysiological hypothesis of immuno-thrombosis or thrombo-inflammation, and data from studies in more severe patients support the existence of a link between inflammation and the procoagulant state (13). Finally, in contrast to the pattern observed in the classic DIC that occurs in sepsis, the thrombocytopenia associated with COVID-19 is mild and there is only a limited consumption of coagulation factors $(11,12,23)$.

In short, the most severe forms of COVID-19 infection give rise to an immune hyper-response that is associated with coagulation disorders.

\section{Pathophysiology of acute VTE in COVID-19 infection}

The thrombotic risk entailed in COVID-19 infection is an emerging problem that has been tackled by numerous publications. VTE is a consequence of the interaction of different pro-thrombotic risk factors related to both the patient and the environment. COVID-19 patients often present risk factors for VTE, such as greater age and obesity, as well as hospitalization for an acute illness $(24,25)$. However, any explanation of a greater thrombotic risk due to COVID-19 itself would suppose that it acts on the main etiopathogenic mechanisms known in VTE: hypercoagulability, endothelial dysfunction and venous stasis-Virchow's triad of the primary inducers of thrombus formation. The pathophysiological mechanisms underlying the association between COVID-19 and thromboembolic complications are still not completely understood, but they seem to involve inflammation, blood hypercoagulability, hypoxia, immobility and DIC, all of which could predispose to the development of thromboembolic complications $(2,3,8,24,26-30)$.
As regards hypercoagulability, we have already seen that coagulation disorders (mainly elevated D-dimer) suggest the existence of a pro-coagulant state in COVID-19 patients, particularly those who are critically ill. Thrombosis is the final stage of inflammation. Therefore, hypercoagulability and the risk of thrombosis could be linked to local and systemic inflammation more than to direct damage from the virus itself (26).

Hypoxia is another factor that could be involved in the coagulopathy associated with COVID-19. It is characteristic of cases of severe pneumonia, and its role in the states of hypercoagulation and thrombosis has been extensively studied (31-33). The cellular response to hypoxia results in the activation of transcriptional factors such as activator protein-1 (AP-1), early growth response protein 1 (Egr-1) and hypoxia-inducible factors (HIF). The most fully investigated of these is HIF-1. Hypoxia leads to the activation of the transcription factor HIF-1, which is responsible for activating a series of proteins involved in the maintenance of vascular homeostasis (34), such as nuclear factor $(\mathrm{NF})-\kappa \mathrm{B}$, vascular endothelial growth factor (VEGF) and erythropoietin (EPO). These proteins enhance a pro-coagulant state, as has been widely reported in cancer patients (35). Moreover, NF- $\mathrm{KB}$ factor mediates the expression of genes encoding for inflammatory cytokines, tumor necrosis factor, chemokines, adhesion molecules and pro-coagulant factors, including the plasminogen activator inhibitor (PAI)-1 and tissue factor pathway inhibitor (36).

As regards the pathophysiology of endothelial dysfunction in COVID-19, pro-thrombotic changes in endothelial cells are the result of the inflammatory environment (Figure 1). Endothelial dysfunction causes the expression of chemo-attractants and adhesion molecules needed to activate monocytes and macrophages, thereby producing tissue factor. Tissue factor then triggers coagulative extrinsic cascades $(16,31)$.

Some authors have suggested that infection by SARSCoV-2 facilitates the induction of endotheliitis in the pulmonary vascular bed as a result of the rapid replication of the virus. This replication causes massive apoptosis of endothelial cells and triggers a loss of anti-coagulant function in the vascular lumen (26).

Lastly, venous stasis in COVID-19 patients is mainly justified by reduced mobility due to the illness.

In short, SARS-CoV-2 infection could provoke VTE through the three classic mechanistic pathways of Virchow's triad: hypercoagulability, endothelial dysfunction and venous stasis. The evidence that is currently available 
suggests that inflammation could be the key factor in the pathophysiology of VTE in COVID-19 patients. Accordingly, the most seriously ill patients develop an inflammatory state that could encourage the development of thrombosis.

\section{Microthrombosis in COVID-19 patients}

COVID-19 patients often pass quickly to a situation of ARDS and multiple organ failure (2). The pathophysiology of ARDS in severe cases of SARS-CoV-2 infection has largely been attributed to a hyper-immune host response. Most of the series of necropsies conducted on patients who died from COVID-19 have shown signs of diffuse alveolar damage with atypical pneumocytes, as well as signs of diffuse microthrombosis on a peripheral level $(4,37,38)$. These findings could explain the severe hypoxemia characteristic of SDRA in COVID-19 patients, the result of the ventilation-perfusion disorder and loss of the hypoxic vasoconstriction reflex; they would also support the hypothesis proposed by some authors that severe forms of COVID-19 are linked to endothelial dysfunction and microvascular thrombosis. Accordingly, the concept of MicroCLOTS (microvascular COVID-19 lung vessels obstructive thrombo-inflammatory syndrome) has been put forward as a pathophysiological hypothesis for the atypical SDRA associated with COVID-19 (39).

However, although this phenomenon of microthrombosis is characteristic of ARDS from COVID-19, it is not exclusive to it, as it is also frequently found in the intermediate evolutionary and proliferative phases of acute alveolar damage of any etiology, along with hyperplasia, atypia and mitosis of type II pneumocytes (40).

As regards acute coronary syndrome (ACS) in COVID-19 patients, plaque rupture has previously been reported in patients with viral disease and explained by vascular or plaque inflammation $(41,42)$. On the one hand, none of the currently available data indicate any greater risk of thrombotic ACS; on the other hand, higher troponin levels in COVID-19 (a biomarker of myocardial injury) have been associated with greater severity $(43,44)$.

\section{Risk of acute VTE in COVID-19 patients}

Seventeen studies have been published to date on the incidence of VTE in COVID-19 patients (Table 1) (45-60,62). Most of these works have included patients admitted to an ICU and were receiving thromboprophylaxis
(Figure 2).

Those studies that included patients admitted to a hospital ward who underwent an imaging test for suspected VTE presented an incidence of PE and/or deep venous thrombosis (DVT) below 5\% $(53,55)$. This rate of symptomatic VTE is not any higher than those obtained in early studies of patients without COVID-19 who were hospitalized for medical causes $(63,64)$.

Critically ill patients have a high risk of developing VTE, with incidences ranging from 13 to $30 \%$ with no antithrombotic prophylaxis $(65,66)$ and from $6 \%$ to $16 \%$ with thromboprophylaxis (67). Similarly, COVID-19 patients in an ICU present a high risk of VTE. Middeldorp et al. studied 198 patients with COVID-19, 74 (37\%) of whom had been admitted to an ICU. The accumulated incidence of VTE at 14 days was higher in those patients in an ICU (48\%; 95\% CI: 33-61\%) than in those in a hospital ward (10\%; 95\% CI: 3-24\%) (53). One study that analyzed the results of all the computerized tomographies of pulmonary arteries performed on COVID-19 patients due to clinical suspicion of $\mathrm{PE}$ or an elevation in $\mathrm{D}$-dimer found an accumulated incidence of $\mathrm{PE}$ of $24 \%$. The incidence was significantly higher in patients in an ICU $(50 \%$; $95 \%$ CI: $30-70 \%)$ than in those in a hospital ward $(18 \% ; 95 \% \mathrm{CI}$ : $12-27 \%)(58)$.

The prevalence of VTE in other studies that included critically ill COVID-19 patients varied from $9 \%$ to $54 \%$, depending on methodological differences and the use of thromboprophylaxis and systematic screening for VTE $(45,48,49,51,52,54,56,57,62)$. In one study by Cui et al. $(45)$, the patients did not receive thromboprophylaxis and the prevalence of VTE was $25 \%$. However, the highest incidence of VTE (54\%) was found in a study by Llitjos et al., even though up to $69 \%$ of the patients had received full doses of anti-coagulants. These results can be partially explained by the disease's severity in the cohort, the state of hypercoagulability and the performance of systematic screening for DVT in the lower limbs via sonography (54).

A French prospective study compared the incidence of thrombotic events in COVID-19 patients in an ICU $(\mathrm{n}=150)$ with non-COVID-19 patients in an ICU $(\mathrm{n}=150)$. By using propensity analysis, the authors found that patients with ARDS due to COVID-19 presented a higher risk of thrombotic events than the non-COVID-19 control group (12\% vs. 5\%; OR 2.6; 95\% CI: 1.1-6.1\%) (53).

The incidence rates of VTE in patients hospitalized for COVID-19 are therefore similar to those published in series investigating other diseases. Although COVID-19 
Table 1 Frequency of VTE in patients with COVID-19 and related risk factors

\begin{tabular}{|c|c|c|c|c|c|c|c|c|c|}
\hline $\begin{array}{l}\text { First author, journal } \\
\text { (reference) }\end{array}$ & $\begin{array}{l}\text { Study design and country of its } \\
\text { population }\end{array}$ & $\mathrm{N}, \%$ males & Mean age & $\begin{array}{l}\text { Patients in ICU } \\
\text { (\%) }\end{array}$ & Criteria for inclusion & Use of thromboprophylaxis & Indication for VTE imaging study & Rate of VTE & Risk factors related to VTE \\
\hline $\begin{array}{l}\text { Cui et al., J Thromb } \\
\text { Haemost (45) }\end{array}$ & Retrospective single-centre, China & $81,46 \%$ & $60 \mathrm{yrs}$ & $100 \%$ & $\begin{array}{l}\text { COVID-19 pneumonia, } \\
\text { admission to ICU }\end{array}$ & No use of thromboprophylaxis & Not specified & $25 \%$, all as DVT & Aged, lymphopenia, prolonged aPTT, DD \\
\hline $\begin{array}{l}\text { Maatman et al., Crit } \\
\text { Care Med (46) }\end{array}$ & Retrospective, multi-centre, USA & $109,57 \%$ & $61 \mathrm{yrs}$ & $100 \%$ & $\begin{array}{l}\text { Confirmed COVID-19 } \\
\text { pneumonia requiring ICU }\end{array}$ & $\begin{array}{l}\text { All patients received thromboprophylaxis: enoxaparin } \\
40 \mathrm{mg} \text { daily, enoxaparin } 30 \mathrm{mg} \text { b/d or UFH 5,000 IU } \\
\text { subcutaneous heparin every } 8 \mathrm{~h}\end{array}$ & Clinical suspicion & $28 \%$ & $\begin{array}{l}\text { Values at admission: Platelet count, } \\
\text { aspartate aminotransferase lactate } \\
\text { dehydrogenase, DD and troponin }\end{array}$ \\
\hline $\begin{array}{l}\text { Al-Samkari et al., } \\
\text { Blood (47) }\end{array}$ & Retrospective, multi-centre, USA & $400,57 \%$ & $62 \mathrm{yrs}$ & $36 \%$ & $\begin{array}{l}\text { Confirmed COVID-19 requiring } \\
\text { hospitalization }\end{array}$ & $\begin{array}{l}97 \% \text { received thromboprophylaxis: standard dose: } \\
88.5 \% \text {; intermediate- or full-dose: } 8.8 \%\end{array}$ & Not specified & $4.8 \%$ & $\begin{array}{l}\text { DD, fibrinogen, C-reactive protein, ferritin, } \\
\text { and procalcitonin }\end{array}$ \\
\hline $\begin{array}{l}\text { Klok et al., Thromb } \\
\text { Res (48) }\end{array}$ & $\begin{array}{l}\text { Retrospective, multi-centre, } \\
\text { Netherlands }\end{array}$ & $184,76 \%$ & $64 \mathrm{yrs}$ & $100 \%$ & $\begin{array}{l}\text { COVID-19 pneumonia, } \\
\text { admission to ICU }\end{array}$ & $\begin{array}{l}\text { All patients with TP at standard dose with Nadroparin } \\
\text { (regime varied according to centre) }\end{array}$ & $\begin{array}{l}\text { Clinical suspicion (according to criteria } \\
\text { of the clinician responsible) }\end{array}$ & $\begin{array}{l}\text { 15\%. Accumulated } \\
\text { incidence } 7 \text { days of } \\
27 \%(95 \% \text { Cl: } 17- \\
37 \%)\end{array}$ & $\begin{array}{l}\text { Age, coagulopathy (PT }>3 \text { seconds and/or } \\
\text { aPT >5 seconds) }\end{array}$ \\
\hline $\begin{array}{l}\text { Klok et al., Thromb } \\
\text { Res (49) }\end{array}$ & $\begin{array}{l}\text { Retrospective, multi-centre, } \\
\text { Netherlands }\end{array}$ & $184,76 \%$ & $64 \mathrm{yrs}$ & $100 \%$ & $\begin{array}{l}\text { COVID-19 pneumonia, } \\
\text { admission to ICU }\end{array}$ & $\begin{array}{l}\text { All patients with TP at standard dose with Nadroparin } \\
\text { (regime varied according to centre) }\end{array}$ & Clinical suspicion & $\begin{array}{l}\text { 37\%. Accumulated } \\
\text { incidence } 14 \text { days } \\
\text { of } 49 \%(95 \% \mathrm{Cl} \text { : } \\
41-57 \%)\end{array}$ & $\begin{array}{l}\text { Long-term anticoagulation was a protective } \\
\text { factor }\end{array}$ \\
\hline $\begin{array}{l}\text { Alonso-Fernández } \\
\text { et al., PLoS One (50) }\end{array}$ & Prospective, single-centre, Spain & $30,63 \%$ & $64 \mathrm{yrs}$ & $38 \%$ & $\begin{array}{l}\text { Hospitalized for COVID-19 } \\
\text { pneumonia and DD } \\
>1,000 \mathrm{ng} / \mathrm{mL}\end{array}$ & Enoxaparin $40 \mathrm{mg}$ daily: $27(90 \%)$ & Elevated DD $(>1,000 \mathrm{ng} / \mathrm{ml})$ & $15 \%$ & Age, DD, platelet count, C-reactive protein \\
\hline $\begin{array}{l}\text { Helms et al., Intensive } \\
\text { Care Medicine, } \\
\text { preprint version (51) }\end{array}$ & $\begin{array}{l}\text { Study of prospective cohort of } \\
\text { consecutive patients, multi-centre, } \\
\text { France }\end{array}$ & $150,81 \%$ & $63 \mathrm{yrs}$ & $100 \%$ & $\begin{array}{l}\text { COVID-19 pneumonia, } \\
\text { admission to ICU }\end{array}$ & $\begin{array}{l}\text { LMWH: prophylactic dose: } 105(70 \%) \text {; therapeutic } \\
\text { dose: } 45(30 \%)\end{array}$ & Clinical suspicion or rapid rise in DD & $18 \%$ & Not studied \\
\hline $\begin{array}{l}\text { Longchamp et al., } \\
\text { Res Pract Thromb } \\
\text { Haemost (52) }\end{array}$ & Retrospective, single-centre, France & $25,64 \%$ & $68 \mathrm{yrs}$ & $100 \%$ & $\begin{array}{l}\text { COVID-19 pneumonia, } \\
\text { admission to ICU }\end{array}$ & $\begin{array}{l}24 / 25(96 \%) \text { patients were prescribed TP: UFH or } \\
\text { enoxaparin at standard prophylactic dose }\end{array}$ & $\begin{array}{l}\text { Lower-limb CCUS was systematically } \\
\text { performed in all patients between days } 5 \\
\text { and } 10 \text { after admission to the ICU. CTPA } \\
\text { performed for clinical suspicion }\end{array}$ & $32 \%$ & Not studied \\
\hline $\begin{array}{l}\text { Middeldorp et al., J } \\
\text { Thromb Haemost, } \\
\text { version preprint (53) }\end{array}$ & $\begin{array}{l}\text { Retrospective study of cohort of } \\
\text { consecutive patients, single-centre, } \\
\text { Netherlands }\end{array}$ & $198,66 \%$ & $61 \mathrm{yrs}$ & $37 \%$ & $\begin{array}{l}\text { Hospitalized for probable or } \\
\text { confirmed COVID-19 }\end{array}$ & $\begin{array}{l}\text { All with nadroparin: <100 kg: 2,850/12 h; } \geq 100 \mathrm{~kg}: \\
5,700 / 12 \mathrm{~h}\end{array}$ & $\begin{array}{l}\text { CTPA for clinical suspicion; CCUS by } \\
\text { randomized selection }\end{array}$ & $\begin{array}{l}17 \% \text {. Accumulated } \\
\text { incidence } 14 \text { days of } \\
34 \%\end{array}$ & $\mathrm{UCl}$ \\
\hline $\begin{array}{l}\text { Llitjos et al., J } \\
\text { Thromb Haemost (54) }\end{array}$ & $\begin{array}{l}\text { Retrospective study of cohort of } \\
\text { consecutive patients, multi-centre, } \\
\text { France }\end{array}$ & $26,77 \%$ & $68 \mathrm{yrs}$ & $100 \%$ & COVID-19, admission to ICU & $\begin{array}{l}\text { Heparin: prophylactic dose: } 18(69 \%) \text {; therapeutic } \\
\text { dose: } 8(31 \%)\end{array}$ & $\begin{array}{l}\text { CCUS in all patients (day 1-3 and day } 7 \text { ). } \\
\text { Study for PE if there is clinical suspicion }\end{array}$ & $54 \%$ & $\begin{array}{l}\text { Anticoagulation at prophylactic vs. } \\
\text { therapeutic doses }\end{array}$ \\
\hline $\begin{array}{l}\text { Lodigiani et al., } \\
\text { Thromb Res (55) }\end{array}$ & $\begin{array}{l}\text { Retrospective study of cohort of } \\
\text { consecutive patients, single-centre, } \\
\text { Italy }\end{array}$ & $388,68 \%$ & $66 \mathrm{yrs}$ & $16 \%$ & $\begin{array}{l}\text { Hospitalized for confirmed } \\
\text { COVID-19 }\end{array}$ & $\begin{array}{l}\text { TP in all patients in ICU and in } 75 \% \text { of those in a } \\
\text { hospital ward }\end{array}$ & Clinical suspicion or rapid rise in $D D$ & $\begin{array}{l}\text { 7.7\%. Accumulated } \\
\text { incidence } 21 \%\end{array}$ & Not studied \\
\hline $\begin{array}{l}\text { Thomas et al., } \\
\text { Thromb Res (56) }\end{array}$ & $\begin{array}{l}\text { Retrospective, single-centre, United } \\
\text { Kingdom }\end{array}$ & $63,69 \%$ & $59 \mathrm{yrs}$ & $100 \%$ & COVID-19, admission to ICU & $\begin{array}{l}\text { All with Dalteparin adjusted to weight and renal } \\
\text { function }\end{array}$ & Clinical suspicion & $\begin{array}{l}\text { 9.5\%. Accumulated } \\
\text { incidence } 27 \%\end{array}$ & Not studied \\
\hline $\begin{array}{l}\text { Poissy et al., } \\
\text { Circulation (57) }\end{array}$ & Retrospective, single-centre, France & $\begin{array}{l}107, \\
\text { unspecified }\end{array}$ & Unspecified & $100 \%$ & COVID-19, admission to ICU & $\begin{array}{l}\text { Antithrombotic prophylaxis with LMWH or UFH, } \\
\text { with no specified dose or percentage of use in the } \\
\text { complete cohort }\end{array}$ & $\begin{array}{l}\text { Clinical suspicion due to respiratory and/ } \\
\text { or acute hemodynamic deterioration }\end{array}$ & $\begin{array}{l}20.6 \% \text {. Accumulated } \\
\text { incidence at } 15 \text { days } \\
\text { of } 20.4 \%\end{array}$ & $\mathrm{DD}$, activity of factor VIII, levels of VWF \\
\hline $\begin{array}{l}\text { Bompard et al., Eur } \\
\text { Respir } J(58)\end{array}$ & Retrospective, multi-centre, France & $135,70 \%$ & 64 yrs & $18 \%$ & $\begin{array}{l}\text { COVID-19 with pneumonia, } \\
\text { with CTPA performed }\end{array}$ & $\begin{array}{l}\text { TP with enoxaparin } 40 \mathrm{mg} / \mathrm{d} \text { in all hospitalized } \\
\text { patients (53\% of total) }\end{array}$ & Clinical suspicion and/or elevated DD & $24 \%$ & $\mathrm{DD}, \mathrm{ICU}, \mathrm{MV}$ \\
\hline
\end{tabular}

Table 1 (continued) 


\begin{tabular}{|c|c|c|c|c|c|c|c|c|c|}
\hline $\begin{array}{l}\text { First author, journal } \\
\text { (reference) }\end{array}$ & $\begin{array}{l}\text { Study design and country of its } \\
\text { population }\end{array}$ & $\mathrm{N}, \%$ males & Mean age & $\begin{array}{l}\text { Patients in ICU } \\
\text { (\%) }\end{array}$ & Criteria for inclusion & Use of thromboprophylaxis & Indication for VTE imaging study & Rate of VTE & Risk factors related to VTE \\
\hline $\begin{array}{l}\text { Demelos et al., } \\
\text { Thromb Res (59) }\end{array}$ & $\begin{array}{l}\text { Prospective observational, single- } \\
\text { centre, Spain }\end{array}$ & $156,65 \%$ & $68 \mathrm{yrs}$ & $\begin{array}{l}10 \% \\
\text { transferred from } \\
\text { ICU }\end{array}$ & $\begin{array}{l}\text { Hospitalized for COVID-19 } \\
\geq 2 \text { days, }>18 \text { years, DD } \\
>1,000 \mathrm{ng} / \mathrm{mL}\end{array}$ & $\begin{array}{l}\text { TP with enoxaparin } 40 \mathrm{mg} / \mathrm{d} \text { or bemiparin 3,500 U//d } \\
\text { in } 153 \text { patients (98\%) }\end{array}$ & CCUS in all patients & $\begin{array}{l}15 \% \text {. All as DVT: } 1 \\
\text { proximal DVT proximal } \\
\text { and } 22 \text { distal DVT }\end{array}$ & DD \\
\hline $\begin{array}{l}\text { Mouhat et al., Eur } \\
\text { Respir J (61) }\end{array}$ & $\begin{array}{l}\text { Retrospective, observational, single- } \\
\text { centre, France }\end{array}$ & $162,67 \%$ & 66 yrs & $42 \%$ ICU & $\begin{array}{l}\text { Hospitalized for COVID-19 and } \\
\text { CTPA performed for severe } \\
\text { disease (SpO2 }<94 \% \text { in room } \\
\text { air or } \mathrm{BR}>29 / \mathrm{min})\end{array}$ & $\begin{array}{l}\text { Anticoagulants in } 87 \% \text { (preventive dose in } 74 \% \text {, } \\
\text { therapeutic doses in } 13 \% \text { ): LMWH in } 85 \% \text {; UFH in } \\
\text { 8\%; oral anticoagulant: } 7 \%\end{array}$ & $\begin{array}{l}\text { All included patients underwent a CTPA } \\
\text { for clinical signs of severe disease. }\end{array}$ & $27 \%$ & $\begin{array}{l}\mathrm{DD}>2,590 \mathrm{ng} / \mathrm{mL} \text {. Lack of any anticoagulant } \\
\text { therapy }\end{array}$ \\
\hline
\end{tabular}


thromboembolism; VWF, von Willebrand factor 


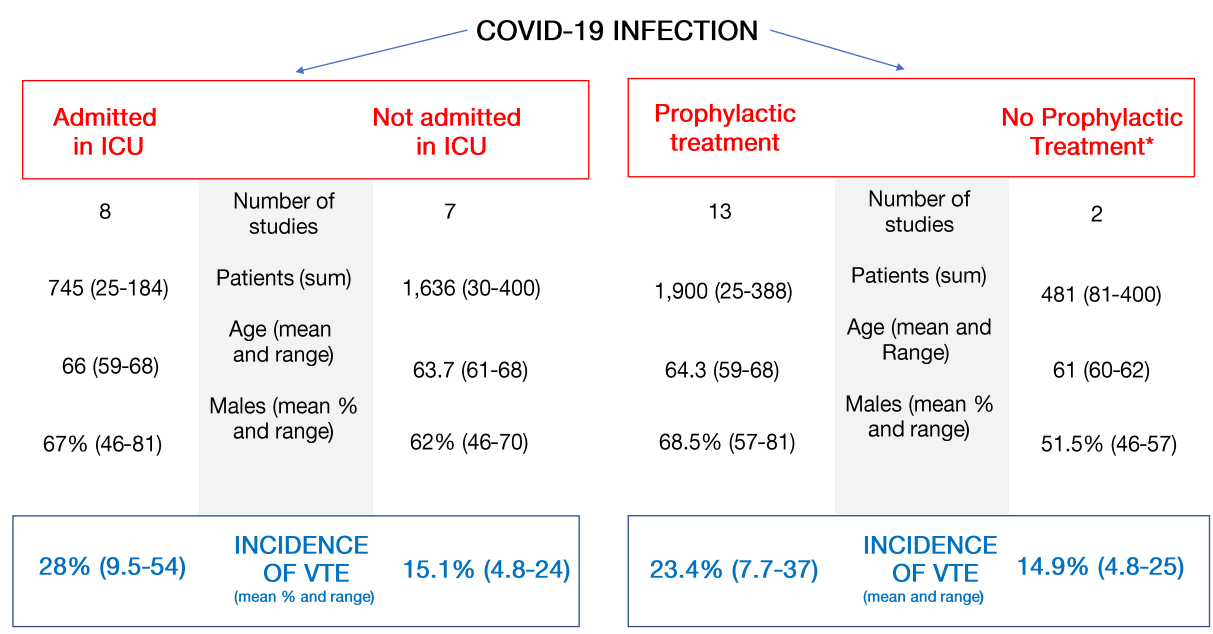

* Only 2 studies without pharmacological thromboprophylaxis

Figure 2 Rates of VTE in patients with COVID-19 infection according to admission to ICU or not (right) or use of pharmacological thromboprophylaxis or not (left). VTE, venous thromboembolism; COVID-19, coronavirus disease 2019; ICU, intensive care unit.

patients in an ICU did present an increased risk of VTE, it is not completely clear whether this is greater than the risk to patients who are critically ill with other diseases (65-67).

\section{VTE prophylaxis in COVID-19 patients}

The prevalence of VTE in patients hospitalized for acute diseases is approximately $10-20 \%$, and consequently the guidelines for clinical practice recommend the use of pharmacological thromboprophylaxis in those patients with a high thrombotic risk, as identified by means of well validated scales [e.g., Caprini score, Padua model, IMPROVE (International Medical Prevention Registry on Venous Thromboembolism)] (24,68-72). The use of prophylactic anticoagulation has been shown to reduce the risk of VTE in acutely ill hospitalized patients, including those hospitalized for infections (e.g., pneumonia). Similarly, VTE risk stratification and in-hospital pharmacological VTE prophylaxis should be applicable for hospitalized COVID-19 patients (71-75). However, some publications have reported that anticoagulant therapy at prophylactic doses may be inadequate for controlling the increased risk of VTE in patients hospitalized for COVID-19 (76).

The authors of a study including 1,026 patients hospitalized for COVID-19 evaluated the baseline thrombotic risk by means of the Padua prediction model and they found that up to $40 \%$ of the patients presented a high risk of VTE (Padua score $>4$ ) (77). Moreover, in a work of Tang et al., a cohort of 449 patients hospitalized for severe COVID-19 showed that the use of heparin at a prophylactic dosage for at least 7 days was associated with reduced mortality in a subgroup of patients with criteria for sepsis-induced coagulopathy (sepsis-induced coagulopathy score $\geq 4$ ) or with very elevated D-dimer ( $>3 \mathrm{mg} / \mathrm{L})(78)$.

Table 2 summarizes the main recommendations of international organizations and scientific societies for thromboprophylaxis in COVID-19 patients (79-85). On the basis of the evidence currently available, the various consensual documents that have been published propose the early use of VTE prophylaxis, unless there are contraindications, in COVID-19 patients requiring admission to a hospital and, more especially, an ICU. Some authors and scientific societies have proposed the use of intermediate- or full-dose parenteral anticoagulation for the routine care of ICU COVID-19 patients, even if VTE has not been confirmed, according to the (as yet undemonstrated) hypothesis of a potential benefit in the prevention of microvascular thrombosis $(48,78,83,85)$. Besides, it has been proposed that anticoagulants could help to reduce not only procoagulant effects in inflammatory conditions but could also reduce proinflammatory stimuli via reduced expression of cytokines and chemokines (86).

One study of critically ill (non-COVID) patients with sepsis found that prophylactic anticoagulation at a standard dose fails in $12 \%$ of patients. It also observed a beneficial effect from the use of high doses of LMWH on gas 
Table 2 Guidelines and recommendations for thromboprophylaxis in COVID-19 patients

\begin{tabular}{|c|c|c|c|c|}
\hline Organization/scientific society & COVID-19 patients & \multicolumn{3}{|c|}{ Recommendations of thromboprophylaxis } \\
\hline World Health Organization (WHO) (75) & $\begin{array}{l}\text { Severe, acute respiratory } \\
\text { infection }\end{array}$ & \multicolumn{3}{|c|}{ LMWH (preferably); unfractionated heparin $5,000 \mathrm{Ul} / 12 \mathrm{~h}$; intermittent pneumatic compression if pharmacological anticoagulation is contraindicated } \\
\hline \multirow{3}{*}{$\begin{array}{l}\text { International Society on Thrombosis and } \\
\text { Heemostasia (ISTH) (74) }\end{array}$} & Out-patient mild disease & \multicolumn{3}{|c|}{ Encouragement of greater mobility; individualized stratification of the thrombotic and hemorrhagic risk } \\
\hline & $\begin{array}{l}\text { Hospitalized moderate or severe } \\
\text { disease with no DIC }\end{array}$ & \multicolumn{3}{|c|}{$\begin{array}{l}\text { Individualized stratification of the thrombotic and hemorrhagic risk; prophylactic doses of LMWH (preferably) or UFH; mechanical thromboprophylaxis (intermittent pneumatic compression) if pharmacological anticoagulation } \\
\text { is contraindicated; therapeutic anticoagulation or intermediate doses not recommended in the absence of confirmed VTE }\end{array}$} \\
\hline & $\begin{array}{l}\text { Hospitalized moderate or severe } \\
\text { disease with DIC }\end{array}$ & \multicolumn{3}{|c|}{$\begin{array}{l}\text { Every patient must receive prophylactic anticoagulation unless there are contraindications (active bleeding and platelet count }<25 \times 10^{\circ} / \text { L); therapeutic anticoagulation or intermediate doses not recommended in the absence } \\
\text { of confirmed VTE; pharmacological thromboprophylaxis considered at discharge for up to } 45 \text { days }\end{array}$} \\
\hline $\begin{array}{l}\text { American Sociedad Americana de } \\
\text { Hematología (ASH) (76) }\end{array}$ & Hospitalized & \multicolumn{3}{|c|}{$\begin{array}{l}\text { All patients must receive pharmacological thromboprophylaxis with LMWH or Fondaparinux (preferable to UFH to reduce contact), unless there is a major risk of hemorrhage; fondaparinux in cases of heparin-induced } \\
\text { thrombocytopenia; mechanical thromboprophylaxis if pharmacological anticoagulation is contraindicated; anticoagulation at therapeutic doses not recommended in the absence of confirmed VTE }\end{array}$} \\
\hline \multirow{20}{*}{$\begin{array}{l}\text { Sociedad Española de Hemostasia y } \\
\text { Trombosis (SETH) (79) }\end{array}$} & Infection without major risk & \multicolumn{3}{|c|}{ LMWH with adjustment of dose to weight and kidney function } \\
\hline & & Enoxaparin & $<80 \mathrm{~kg}: 40 \mathrm{mg} / 24 \mathrm{~h} ; 80-100 \mathrm{~kg}: 60 \mathrm{mg} / 24 \mathrm{~h} ;>100 \mathrm{~kg}: 40 \mathrm{mg} / 12 \mathrm{~h}$ & $<80 \mathrm{~kg}: 20 \mathrm{mg} / 24 \mathrm{~h} ;>80 \mathrm{~kg}: 40 \mathrm{mg} / 24 \mathrm{~h}$ \\
\hline & & Tinzaparin & $<60 \mathrm{~kg}: 3,500 \mathrm{UI} / 24 \mathrm{~h} ;>60 \mathrm{~kg}: 4,500 \mathrm{UI} / 24 \mathrm{~h}$ & $<60 \mathrm{~kg}: 3,500 \mathrm{U} / 24 \mathrm{~h} ;>60 \mathrm{~kg}: 4,500 \mathrm{UI} / 24 \mathrm{~h}$ \\
\hline & & Bemiparin & $3500 \mathrm{UI} / 24 \mathrm{~h}$ & $2,500 \mathrm{Ul} / 24 \mathrm{~h}$ \\
\hline & & Nadroparin & $0.3 \mathrm{~mL} / 24 \mathrm{~h}$ & - \\
\hline & & Dalteparin & $5,000 \mathrm{Ul} / 24 \mathrm{~h}$ & - \\
\hline & & \multicolumn{3}{|c|}{ Fondaparinux if there is allergy to heparin or heparin-induced thrombocytopenia } \\
\hline & & \multicolumn{2}{|c|}{ Creatinine clearance $>50 \mathrm{~mL} / \mathrm{min}$} & $2.5 \mathrm{mg} / 24 \mathrm{~h}$ \\
\hline & & \multicolumn{2}{|c|}{ Creatinine clearance $<50$ and $>20 \mathrm{~mL} / \mathrm{min}$} & $2.5 \mathrm{mg} / 24 \mathrm{~h}$ \\
\hline & & \multicolumn{2}{|c|}{ Creatinine clearance $<20 \mathrm{~mL} / \mathrm{min}$} & Contraindicated \\
\hline & & & Creatinine clearance $>30 \mathrm{~mL} / \mathrm{min}$ & Creatinine clearance $<30 \mathrm{~mL} / \mathrm{min}$ \\
\hline & & Enoxaparin & $1 \mathrm{mg} / \mathrm{kg} / 24 \mathrm{~h}$ & $0.5 \mathrm{mg} / \mathrm{kg} / 24 \mathrm{~h}$ \\
\hline & & Tinzaparin & $75 \mathrm{Ul} / \mathrm{kg} / 24 \mathrm{~h}$ & $75 \mathrm{Ul} / \mathrm{kg} / 24 \mathrm{~h}$ \\
\hline & & Bemiparin & $5,000 \mathrm{Ul} / 24 \mathrm{~h}$ & $3,500 \mathrm{Ul} / 24 \mathrm{~h}$ \\
\hline & & Nadroparin & $<70 \mathrm{~kg}: 0.4 \mathrm{~mL} / 24 \mathrm{~h} ;>70 \mathrm{~kg}: 0.6 \mathrm{~mL} / 24 \mathrm{~h}$ & - \\
\hline & & Dalteparin & $5,000 \mathrm{UI} / 24 \mathrm{~h}$ & - \\
\hline & & \multicolumn{3}{|c|}{ Fondaparinux if there is allergy to heparin or heparin-induced thrombocytopenia: } \\
\hline & & \multicolumn{2}{|c|}{ Creatinine clearance $>50 \mathrm{~mL} / \mathrm{min}$} & $5 \mathrm{mg} / 24 \mathrm{~h}$ \\
\hline & & \multicolumn{2}{|c|}{ Creatinine clearance $<50$ and $>20 \mathrm{~mL} / \mathrm{min}$} & $2.5 \mathrm{mg} / 24 \mathrm{~h}$ \\
\hline & & \multicolumn{2}{|c|}{ Creatinine clearance $<20 \mathrm{~mL} / \mathrm{min}$} & Contraindicated \\
\hline Thrombosis UK (77) & Hospitalized & \multicolumn{3}{|c|}{$\begin{array}{l}\text { Evaluation of thrombotic risk in all the patients (NICE/ ASH). LMWH, unless contraindicated, if there is immobilization and criteria of severity: Creatinine clearance }>30 \text { : LMWH or Fondaparinux s.c. Creatinine clearance }<30 \text { : } \\
\text { UFH } 5000 \text { U I s.C. or low dose of LMWH. All patients with complete immobilization are recommended intermittent pneumatic compression, as well as pharmacological thromboprophylaxis. Mechanical thromboprophylaxis } \\
\text { exclusively if platelets }<30,000 \text { or bleeding }\end{array}$} \\
\hline $\begin{array}{l}\text { Working Group on Cardiovascular } \\
\text { Thrombosis of the Sociedad Española de } \\
\text { Cardiologia (77) }\end{array}$ & Hospitalized & \multicolumn{3}{|c|}{$\begin{array}{l}\text { All hospitalized patients must receive } L M W H \text {; adjustment of the dose is recommended inBMI>35 and after evaluating the hemorrhagic risk and the platelet count. In patients with criteria of severity and high thrombotic risk, } \\
\text { LMWH is recommended at intermediate/extended or therapeutic doses, following an evaluation of the hemorrhagic risk. Prolongation of } L M W H \text { at prophylactic doses for } 7-10 \text { days after the hospital discharge }\end{array}$} \\
\hline \multirow[t]{2}{*}{ British Thorax Society (BTS) (80) } & Low risk & \multicolumn{3}{|c|}{ Weight-adjusted prophylactic dose (e.g., $70 \mathrm{~kg}$ with creatinine clearance $>30 \mathrm{~mL} / \mathrm{min}$ : Dalteparin 5,000 Ul/day, enoxaparin $40 \mathrm{mg} /$ day) } \\
\hline & High risk & \multicolumn{3}{|c|}{ LMWH at intermediate doses (e.g., $70 \mathrm{~kg}$ with creatinine clearance $>30 \mathrm{~mL} / \mathrm{min}$ : Dalteparin 5,000 U//12h, enoxaparin $40 \mathrm{mg} / 12 \mathrm{~h}$ ) } \\
\hline
\end{tabular}


exchange $\left(\mathrm{PaO}_{2} / \mathrm{FiO}_{2}\right)$ in a subgroup of patients with ARDS who received high doses of LMWH (87). The existing data are still very limited, however, and the optimal anticoagulant dose in patients with severe COVID-19 remains unknown, and so further prospective investigation is required.

Similarly, further research needs to be conducted on the use of weight-adjusted thromboprophylaxis in COVID-19 patients, as there have been no studies on this topic to date. Its use has probably been justified by the fact that overweight patients were underrepresented in the pivotal clinical trials $(63-65,88,89)$ and in the data obtained in a systematic review of obese patients who underwent bariatric surgery, which showed a (not statistically significant) trend towards a reduction in VTE events in individuals who received weight-adjusted thromboprophylaxis $(0.5 \% \mathrm{vs}$. $2.0 \%)$, without any increase in the risk of hemorrhage $(1.6 \%$ vs. $2.3 \%)(90)$.

Another point of controversy is the use of extended thromboprophylaxis after hospitalization in COVID-19 patients (91). Studies of extended thromboprophylaxis in patients with acute diseases have not demonstrated any net beneficial effect, and the current guidelines for clinical practice only recommend its use during a patient's hospitalization $(61,92)$. In the case of COVID-19 patients, although there is no still evidence about the risk of post-discharge VTE and major bleeding rates in COVID-19, some experts have suggested the possibility of individualizing the use of extended VTE prophylaxis (for a month, or even 45 days) considering the net benefit between risk factors for VTE (e.g., reduced mobility, obesity, previous VTE, active cancer, etc.) and low risk of hemorrhage $(24,93)$.

At the moment, there is evidence available on the role of thromboprophylaxis in a patient who presents concomitant mild COVID-19 and significant comorbidities but has not been hospitalized. The consensus document by Bikdeli et al. on patients confined with mild COVID-19 without requiring hospital admission recommends encouraging mobility and considering individualized pharmacological prophylaxis in those with a high risk of VTE and a low risk of hemorrhage (27).

Mechanical prophylaxis with intermittent pneumatic compression should only be used in immobilized patients if pharmacological prophylaxis is contraindicated (94).

Furthermore, it must be remembered that the main complication associated with anticoagulant treatment is bleeding. A recent multicentre retrospective study has assessed the rate of bleeding in 400 patients hospitalized for COVID-19 (144 critically ill), all receiving standarddose prophylactic anticoagulation. The authors found that the overall and major bleeding rates were $5 \%$ (95\% CI, $2.9-7.3 \%$ ) and $2 \%$ (95\% CI, 1.0-4.2\%), respectively, almost all in critically ill patients (47).

In any case, there are no reliable data at present on the real rate of thrombotic and hemorrhagic events in COVID-19 patients, and neither do we know the efficacy and safety of the various strategies used for thromboprophylaxis, or the risk profiles involved. We therefore need results from well-designed clinical studies that would show the benefits of different strategies of anticoagulants in COVID-19 patients (clinicaltrials.org), although this could vary according to patients' specific individual characteristics (e.g., thrombotic risk factors, disease severity) (Table 3).

\section{Diagnosis of acute VTE in COVID-19 patients}

VTE is diagnosed via well-validated algorithms that combine scales of clinical probability (e.g., Wells, Geneva, YEARS), D-dimer results and imaging tests (29). A normal $\mathrm{D}$-dimer value rules out a diagnosis of VTE in patients with a low or intermediate clinical suspicion. An imaging test is required to confirm the diagnosis in patients with a high clinical probability (due to the low negative predictive value of $\mathrm{D}$-dimer in this subgroup) or a positive $\mathrm{D}$-dimer value (due to the low specificity of D-dimer for the diagnosis of VTE) $(24,93)$.

However, as mentioned above, an elevated D-dimer level is a common finding in COVID-19 patients $(2-4,6,7,14)$ and the classic cut-off point $(0.5 \mathrm{mg} / \mathrm{L})$ excludes very few patients from the need for a confirmatory imaging test, computed tomography pulmonary angiogram (CTPA) and/or lower-limb ultrasound (in the case of clinical suspicion of PE and/or DVT, respectively). Moreover, bedside cardiac ultrasound could be worth considering in patients with hemodynamic instability, to assess for signs of right ventricular dysfunction and, in exceptional cases, the presence of a clot in transit $(24,95)$. Given the lack of specificity of the respiratory symptoms in COVID-19 patients (particularly the most seriously ill), experts have recommended a high degree of clinical suspicion, particularly when there is any deterioration on a respiratory (e.g., hypoxemia disproportionate to lung involvement) or hemodynamic level (acute unexplained right ventricular dysfunction) $(25,96)$.

Furthermore, it must be borne in mind the risk of 
Table 3 Future challenges for the study of thrombotic risk in COVID-19 patients

\begin{tabular}{|c|c|}
\hline Variable & Challenges \\
\hline \multirow[t]{2}{*}{ Epidemiology } & $\begin{array}{l}\text { To prospectively determine the real incidence of VTE in population-based studies, in out-patient vs. hospitalized } \\
\text { patients, and according to the severity of COVID-19 }\end{array}$ \\
\hline & To determine the risk of VTE in pregnant COVID-19 patients \\
\hline \multirow[t]{4}{*}{ Prevention of VTE } & To determine the optimal risk stratification for consideration of VTE prophylaxis \\
\hline & $\begin{array}{l}\text { To assess the efficacy and safety of different anticoagulant doses (prophylactic doses and others) to find the optimal } \\
\text { anti-thrombotic strategy, preferably through RCT }\end{array}$ \\
\hline & To assess the efficacy and safety of extended (post-discharge) thromboprophylaxis, preferably through RCT \\
\hline & $\begin{array}{l}\text { To assess the impact of pharmacological thromboprophylaxis in pregnant COVID-19 patients, and during the } \\
\text { postpartum period }\end{array}$ \\
\hline \multirow[t]{3}{*}{ Diagnosis of VTE } & $\begin{array}{l}\text { To determine the most appropriate diagnostic algorithm of incident thrombotic events for patients with suspected VTE } \\
\text { and COVID-19 infection }\end{array}$ \\
\hline & $\begin{array}{l}\text { To prospectively assess the efficacy of classical predictor scores to identify VTE among COVID-19 patients (e.g., Well } \\
\text { score, Geneva score) }\end{array}$ \\
\hline & To develop and validate a novel specific score to predict VTE among hospitalized COVID-19 patients \\
\hline \multirow{2}{*}{ Outcomes of VTE } & $\begin{array}{l}\text { To assess the risk of persistent symptoms of exercise intolerance and dyspnea (post-PE syndrome including CTED } \\
\text { and CTEPH) during the follow-up (>3 months of anticoagulant therapy) in COVID-19 patients with concomitant PE vs. } \\
\text { without concomitant PE }\end{array}$ \\
\hline & To evaluate the risk of recurrent VTE after stopping anticoagulation \\
\hline
\end{tabular}

COVID-19, coronavirus disease 2019; CTED, chronic thromboembolic disease; CTEPH, chronic thromboembolic pulmonary hypertension; PE, pulmonary embolism; RCT, randomized clinical trials; VTE, venous thromboembolism.

transmitting infection to health care workers who perform these imaging tests or other patients, with the added difficulty that some patients could be required to be in a prone position for severe ARDS.

One recent retrospective study on 162 patients hospitalized for COVID-19 pneumonia with clinical signs of severity who underwent CTPA in order to rule out PE analyzed the predictive value of $\mathrm{D}$-dimer for the diagnosis of $\mathrm{PE}$. A
D-dimer cut-off value of $2.59 \mathrm{mg} / \mathrm{L}$ was identified as the best for predicting the occurrence of PE (AUC: $0.88, \mathrm{P}<0.001$, sensitivity $83.3 \%$, specificity $83.8 \%$ ) and it was associated with a 17 -fold increase in the adjusted risk of PE (62).

\section{Treatment of acute VTE in COVID-19 patients}

Therapeutic anticoagulation is currently the treatment of 
choice for confirmed VTE (24) although, as mentioned above, there is insufficient scientific evidence to support the use of full-dose anticoagulation in COVID-19 patients. The choice of agents and dosage for the treatment of incident acute VTE in hospitalized COVID-19 patients should be based on current guidelines, but the pharmacological interactions between some COVID-19 therapies and oral anticoagulants [both vitamin $\mathrm{K}$ antagonists (VKA) and direct oral anticoagulants (DOAC)], and the difficulties involved in performing regular out-patient controls of the activity of VKAs render LMWHs in monotherapy the anticoagulant treatment of choice, at least during the first weeks after the thrombotic episode (72). Parenteral anticoagulation has the advantages that it can be withdrawn temporally, does not need to be monitored it and has not demonstrated any drug-drug interactions with routine COVID-19 therapies. Furthermore, a daily dosing regimen of LMWH could have the benefit over unfractionated heparin of reducing health care workers' risk of exposure $(27,97)$. Using oral anticoagulation with DOACs also may offer some potential advantages, such as easier out-patient management, reduced contact between health care workers and patients and a lack of any need for monitoring $(24,27)$.

One topic of particular interest is the option of therapeutic anticoagulant management for patients with a diagnosis of incidental acute PE with isolated sub-segmental filling defects in the CTPA. Some recent publications have shown that the incidental acute PE found in COVID-19 patients is characterized radiologically by an overall thrombotic load that is low (as assessed by the Qanadli index), less extensive and predominantly peripheral (more frequently involving only sub-segmental branches), so this issue acquires a special significance in the handling of these patients $(98,99)$. The current guidelines, mostly based on expert opinions due to limited data, indicate that the clinical relevance of the CTPA diagnosis of sub-segmental $\mathrm{PE}$ remains unknown, although anticoagulant treatment is recommended in cases of single sub-segmental PE in a hospitalized patient and/or multiple sub-segmental PE (29).

Invasive treatment for acute VTE in COVID-19 patients (e.g., catheter-directed therapies, surgical embolectomy) must be restricted to situations backed by more evidence, due to the risk of contagion to both other patients and health care workers, and the prevailing guidelines must be followed. For example, the placement of an inferior vena cava filter is an adequate treatment for VTE in a setting with absolute contraindications (24).

As regards those patients hospitalized for COVID-19 who received previous oral anticoagulant treatment (atrial fibrillation, valvulopathy, VTE, etc.), a change to HBPM at therapeutic doses is recommended, to avoid any pharmacological interactions with the drugs used to treat COVID-19 and facilitate the hospital management of patients who are potentially seriously ill or vulnerable. This change is proposed until the clinical picture is resolved and/ or the pharmacological interaction has finished, bearing in mind the half-life of the drugs involved (84).

\section{Future challenges}

The issue of COVID-19 infection and coagulation disorders/ thrombotic risk is one of the most important aspects that need more extensive and higher-quality data if the management of COVID-19 patients is to be improved. The data currently available is still very limited, and there are gaps in our knowledge that require further research. The challenge now is to adequately fill these gaps. Table 3 shows some of the studies that will be required for this purpose in the future.

All these issues provide opportunities for improving the management of these patients and for answering questions that are having such an enormous clinical impact. Close collaboration will be required between VTE and COVID-19 working groups.

\section{Conclusions}

The research now emerging highlights the complex interactions between COVID-19 infection and thrombotic disease. COVID-19 infection induces a pro-thrombotic state, secondary to the organism's hyper-inflammatory response and to hypoxia, which can predispose to an increased incidence of venous thrombotic events, particularly in the most severely ill patients. The results presented in recent scientific publications on the coagulopathy associated with COVID-19 and the risk of thrombotic events have triggered debate and controversy about the optimal strategy for the prophylaxis, diagnosis and anti-thrombotic treatment of VTE, as reflected by the divergences in the recommendations published by various scientific organizations and societies. It is still not clear whether the failure rate of pharmacological thromboprophylaxis is higher in critically ill COVID-19 patients than in others who are critically ill from other diseases; this doubt has led some authors to recommend the use of thromboprophylaxis at intermediate doses 
or therapeutic anticoagulation in this patient profile, although we would need to have results from the clinical trials current underway to endorse these proposals. The diagnosis of VTE in COVID-19 patients presents certain difficulties and traits that must be taken into account, such as the risk of contagion of other patients and of health care workers and the overlap of respiratory symptoms that can be explained by both respiratory infection and the presence of acute PE. While we await the definition of the diagnostic algorithm for VTE most suited to patients hospitalized for COVID-19, it seems reasonable to maintain a high degree of clinical suspicion of $\mathrm{PE}$ and/or DVT in these patients, in order to determine the optimal antithrombotic treatment. The treatment of incidental VTE in patients with pneumonia due to SARS$\mathrm{CoV}-2$ should follow the recommendations proposed by the scientific societies, taking into account the benefits to these patients of parenteral anticoagulant treatment, at least during their hospital stay.

To conclude, there is a critical need for rigorous, wellpowered studies that will determine the optimal algorithm for the diagnosis of incident VTE in COVID-19 patients and the impact of anticoagulants and antiplatelet agents on the primary and secondary prevention of VTE in these patients. Future studies could benefit from the careful identification of subgroups most likely to present thrombotic complications, as well as from larger sample sizes and the incorporation of predictive scores.

\section{Acknowledgments}

Funding: None.

\section{Footnote}

Reporting Checklist: The authors have completed the PRISMA reporting checklist. Available at http://dx.doi. org/10.21037/jtd-20-3062

Conflicts of Interest: All authors have completed the ICMJE uniform disclosure form (available at http://dx.doi. org/10.21037/jtd-20-3062). All authors have no conflicts of interest to declare.

Ethical Statement: The authors are accountable for all aspects of the work in ensuring that questions related to the accuracy or integrity of any part of the work are appropriately investigated and resolved.
Open Access Statement: This is an Open Access article distributed in accordance with the Creative Commons Attribution-NonCommercial-NoDerivs 4.0 International License (CC BY-NC-ND 4.0), which permits the noncommercial replication and distribution of the article with the strict proviso that no changes or edits are made and the original work is properly cited (including links to both the formal publication through the relevant DOI and the license). See: https://creativecommons.org/licenses/by-nc-nd/4.0/.

\section{References}

1. Zhu N, Zhang D, Wang W, et al. A novel coronavirus from patients with pneumonia in china, 2019. N Engl J Med 2020;382:727-33.

2. Guan WJ, Ni Z, Hu Y, et al. Clinical characteristics of coronavirus disease 2019 in china. $\mathrm{N}$ Engl J Med 2020;382:1708-20.

3. Huang C, Wang Y, Li X, et al. Clinical features of patients infected with 2019 novel coronavirus in Wuhan, China. Lancet 2020;395:497-506.

4. Wu C, Chen X, Cai Y, et al. Risk factors associated with acute respiratory distress syndrome and death in patients with coronavirus disease 2019 pneumonia in Wuhan, China. JAMA Intern Med 2020;180:934-43.

5. Connors JM, Levy JH. Thromboinflammation and the hypercoagulability of COVID-19. J Thromb Haemost 2020;18:1559-61.

6. Wang D, Hu B, Hu C, et al. Clinical characteristics of 138 hospitalized patients with 2019 novel coronavirus-infected pneumonia in Wuhan, China. JAMA 2020;323:1061-9.

7. Tang N, Li D, Wang X, et al. Abnormal coagulation parameters are associated with poor prognosis in patients with novel coronavirus pneumonia. J Thromb Haemost 2020;18:844-7.

8. Zhou F, Yu T, Du R, et al. Clinical course and risk factors for mortality of adult inpatients with COVID-19 in wuhan, china: A retrospective cohort study. Lancet 2020;395:1054-62.

9. Lippi G, Favaloro EJ. D-dimer is associated with severity of coronavirus disease 2019: A pooled analysis. Thromb Haemost 2020;120:876-8.

10. Terpos E, Ntanasis Stathopoulos I, Elalamy I, et al. Hematological findings and complications of COVID-19. Am J Hematol 2020;95:834-47.

11. Connors JM, Levy JH. COVID-19 and its implications for thrombosis and anticoagulation. Blood 2020;135:2033-40.

12. Mehta P, McAuley DF, Brown M, et al. COVID-19: 
Consider cytokine storm syndromes and immunosuppression. Lancet 2020;395:1033-4.

13. Ranucci M, Ballotta A, Di Dedda U, et al. The procoagulant pattern of patients with COVID-19 acute respiratory distress syndrome. J Thromb Haemost 2020;18:1747-51.

14. Fogarty H, Townsend L, Ni Cheallaigh C, et al. COVID-19 Coagulopathy in Caucasian patients. Br J Haematol 2020;189:1060-1.

15. Han H, Yang L, Liu R, et al. Prominent changes in blood coagulation of patients with SARS-CoV-2 infection. Clin Chem Lab Med 2020;58:1116-20.

16. Vidali S, Morosetti D, Cossu E, et al. D-dimer as an indicator of prognosis in SARS-CoV-2 infection: a systematic review. ERJ Open Res 2020;6:00260-2020.

17. López-Reyes R, Oscullo G, Jiménez D, et al. Thrombotic Risk and Covid-19: Review of Current Evidence for a Better Diagnostic and Therapeutic Approach. Arch Bronconeumol 2020:S0300-2896(20)30268-4.

18. Iba T, Levy JH. Inflammation and thrombosis: Roles of neutrophils, platelets and endothelial cells and their interactions in thrombus formation during sepsis. J Thromb Haemost 2018;16:231-41.

19. Iba T, Levy JH, Thachil J, et al. The progression from coagulopathy to disseminated intravascular coagulation in representative underlying diseases. Thromb Res 2019;179:11-4.

20. Iba T, Levy JH, Warkentin TE, et al. Diagnosis and management of sepsis-induced coagulopathy and disseminated intravascular coagulation. J Thromb Haemost 2019;17:1989-94.

21. Mendoza-Pinto C, García-Carrasco M, Cervera R. Role of Infectious Diseases in the Antiphospholipid Syndrome (Including Its Catastrophic Variant). Curr Rheumatol Rep 2018;20:62.

22. Esmon CT. The impact of the inflammatory response on coagulation. Thromb Res 2004;114:321-7.

23. van der Poll T, de Jonge E, Levi M. Regulatory role of cytokines in disseminated intravascular coagulation. Semin Thromb Hemost 2001;27:639-51.

24. Konstantinides SV, Meyer G, Becattini C, et al. 2019 ESC Guidelines for the diagnosis and management of acute pulmonary embolism developed in collaboration with the European Respiratory Society (ERS): The Task Force for the diagnosis and management of acute pulmonary embolism of the European Society of Cardiology (ESC). Eur Respir J 2019;54:1901647.

25. Rogers MA, Levine DA, Blumberg N, et al. Triggers of hospitalization for venous thromboembolism. Circulation 2012;125:2092-9.

26. Iba T, Levy JH, Levi M, et al. Coagulopathy of Coronavirus Disease 2019. Crit Care Med 2020;10.1097/ CCM.0000000000004458.

27. Bikdeli B, Madhavan MV, Jimenez D, et al. COVID-19 and Thrombotic or Thromboembolic Disease: Implications for Prevention, Antithrombotic Therapy, and Follow-up. J Am Coll Cardiol 2020;S07351097(20)35008-7.

28. Smeeth L, Cook C, Thomas S, et al. Risk of deep vein thrombosis and pulmonary embolism after acute infection in a community setting. Lancet 2006;367:1075-9.

29. Samama MM. An epidemiologic study of risk factors for deep vein thrombosis in medical outpatients: the Sirius study. Arch Intern Med 2000;160:3415-20.

30. Frasson S, Gussoni G, Di Micco P, et al. Infection as cause of immobility and occurrence of venous thromboembolism: analysis of 1635 medical cases from the RIETE registry. J Thromb Thrombolysis 2016;41:404-12.

31. Eltzschig HK, Carmeliet P. Hypoxia and inflammation. N Engl J Med 2011;364:656-65.

32. Kumar DR, Hanlin E, Glurich I, et al. Virchow's contribution to the understanding of thrombosis and cellular biology. Clin Med Res 2010;8:168-72.

33. Prchal JT. Hypoxia and thrombosis. Blood 2018;132:348-9.

34. Semenza GL. HIF-1: mediator of physiological and pathophysiological responses to hypoxia. J Appl Physiol 2000;88:1474-80.

35. Evans CE, Bendahl PO, Belting $M$, et al. Diverse roles of cell-specific hypoxia-inducible factor 1 in cancer-associated hypercoagulation. Blood 2016;127:1355-60.

36. Taylor CT, Cummins EP. The role of NF-kappaB in hypoxia-induced gene expression. Ann N Y Acad Sci 2009;1177:178-84.

37. Ding Y, Wang H, Shen H, et al. The clinical pathology of severe acute respiratory syndrome (SARS): a report from China. J Pathol 2003;200:282-9.

38. Fox S, Akmatbekov A, Harbert JL, et al. Pulmonary and Cardiac Pathology in Covid-19: The First Autopsy Series from New Orleans. medRxiv 2020.04.06.20050575. doi: 10.1101/2020.04.06.20050575.

39. Ciceri F, Beretta L, Scandroglio AM, et al. Microvascular COVID-19 lung vessels obstructive thromboinflammatory syndrome (MicroCLOTS): An atypical acute respiratory distress syndrome working hypothesis. Crit Care Resusc 2020;22:95-7. 
40. Bone RC, Francis PB, Pierce AK. Intravascular coagulation associated with the adult respiratory distress syndrome. Am J Med 1976;61:585-9.

41. Madjid M, Aboshady I, Awan I, et al. Influenza and cardiovascular disease: is there a causal relationship? Tex Heart Inst J 2004;31:4-13.

42. Madjid M, Naghavi M, Litovsky S, et al. Influenza and cardiovascular disease: a new opportunity for prevention and the need for further studies. Circulation 2003;108:2730-6.

43. Driggin E, Madhavan MV, Bikdeli B, et al. Cardiovascular Considerations for Patients, Health Care Workers, and Health Systems During the COVID-19 Pandemic. J Am Coll Cardiol 2020;75:2352-71.

44. Lippi G, Lavie CJ, Sanchis-Gomar F. Cardiac troponin I in patients with coronavirus disease 2019 (COVID-19): Evidence from a meta-analysis. Prog Cardiovasc Dis 2020;63:390-1.

45. Cui S, Chen S, Li X, et al. Prevalence of venous thromboembolism in patients with severe novel coronavirus pneumonia. J Thromb Haemost 2020;18:1421-4.

46. Maatman TK, Jalali F, Feizpour C, et al. Routine Venous Thromboembolism Prophylaxis May Be Inadequate in the Hypercoagulable State of Severe Coronavirus Disease 2019. Crit Care Med 2020;48:e783-90.

47. Al-Samkari H, Karp Leaf RS, Dzik WH, et al. COVID-19 and coagulation: bleeding and thrombotic manifestations of SARS-CoV-2 infection. Blood 2020;136:489-500.

48. Klok FA, Kruip MJHA, van der Meer NJM, et al. Incidence of thrombotic complications in critically ill ICU patients with COVID-19. Thromb Res 2020;191:145-7.

49. Klok FA, Mjha K, van der Meer NJM, et al. Confirmation of the high cumulative incidence of thrombotic complications in critically ill ICU patients with COVID-19: An updated analysis. Thromb Res 2020;191:148-50.

50. Alonso-Fernández A, Toledo-Pons N, Cosío BG, et al. Prevalence of pulmonary embolism in patients with COVID-19 pneumonia and high D-dimer values: A prospective study. PLoS One 2020;15:e0238216.

51. Helms J, Tacquard C, Severac F, et al. High risk of thrombosis in patients in severe SARS-CoV-2 infection: a multicentre prospective cohort study. Intensive Care Med 2020;46:1089-98.

52. Longchamp A, Longchamp J, Manzocchi-Besson S, et al. Venous thromboembolism in critically Ill patients with COVID-19: Results of a screening study for deep vein thrombosis. Res Pract Thromb Haemost 2020;4:842-7.

53. Middeldorp S, Coppens M, Haaps TFv, et al. Incidence of Venous Thromboembolism in Hospitalized Patients with COVID-19. J Thromb Haemost 2020;18:1995-2002.

54. Llitjos JF, Leclerc M, Chochois C, et al. High incidence of venous thromboembolic events in anticoagulated severe COVID-19 patients. J Thromb Haemost 2020;18:1743-6.

55. Lodigiani C, Iapichino G, Carenzo L, et al. Venous and arterial thromboembolic complications in COVID-19 patients admitted to an academic hospital in Milan, Italy. Thromb Res 2020;191:9-14.

56. Thomas W, Varley J, Johnston A, et al. Thrombotic complications of patients admitted to intensive care with COVID-19 at a teaching hospital in the United Kingdom. Thromb Res 2020;191:76-7.

57. Poissy J, Goutay J, Caplan M, et al. Pulmonary Embolism in COVID-19 Patients: Awareness of an Increased Prevalence. Circulation 2020;142:184-6.

58. Bompard F, Monnier H, Saab I, et al. Pulmonary embolism in patients with Covid-19 pneumonia. Eur Respir J 2020;56:2001365.

59. Demelo-Rodríguez P, Cervilla-Muñoz E, Ordieres-Ortega $\mathrm{L}$, et al. Incidence of asymptomatic deep vein thrombosis in patients with COVID-19 pneumonia and elevated D-dimer levels. Thromb Res 2020;192:23-6.

60. Poyiadji N, Cormier P, Patel PY, et al. Acute Pulmonary Embolism and COVID-19. Radiology 2020;297:E335-8.

61. Dentali F, Mumoli N, Prisco D, et al. Efficacy and safety of extended thromboprophylaxis for medically ill patients. A meta-analysis of randomised controlled trials. Thromb Haemost 2017;117:606-17.

62. Mouhat B, Besutti M, Bouiller K, et al. Elevated D-dimers and lack of anticoagulation predict PE in severe COVID-19 patients. Eur Respir J 2020;56:2001811.

63. Samama MM, Cohen AT, Darmon JY, et al. A comparison of enoxaparin with placebo for the prevention of venous thromboembolism in acutely ill medical patients. Prophylaxis in Medical Patients with Enoxaparin Study Group. N Engl J Med 1999;341:793-800.

64. Leizorovicz A, Cohen AT, Turpie AGG, et al. Randomized, placebo-controlled trial of dalteparin for the prevention of venous thromboembolism in acutely ill medical patients. Circulation 2004;110:874-9.

65. Cohen AT, Davidson BL, Gallus AS, et al. Efficacy and safety of fondaparinux for the prevention of venous thromboembolism in older acute medical patients: randomised placebo controlled trial. BMJ 2006;332:325-9.

66. Moser KM, LeMoine JR, Nachtwey FJ, et al. Deep venous 
thrombosis and pulmonary embolism. Frequency in a respiratory intensive care unit. JAMA 1981;246:1422-4.

67. Geerts W, Cook D, Selby R, et al. Venous thromboembolism and its prevention in critical care. J Crit Care 2002;17:95-104.

68. Minet C, Potton L, Bonadona A, et al. Venous thromboembolism in the ICU: main characteristics, diagnosis and thromboprophylaxis. Crit Care 2015;19:287.

69. Kearon C, Akl EA, Ornelas J, et al. Antithrombotic Therapy for VTE Disease: CHEST Guideline and Expert Panel Report. Chest 2016;149:315-52.

70. Dentali F, Douketis JD, Gianni M, et al. Meta-analysis: anticoagulant prophylaxis to prevent symptomatic venous thromboembolism in hospitalized medical patients. Ann Intern Med 2007;146:278-88.

71. Wein L, Wein S, Haas SJ, et al. Pharmacological venous thromboembolism prophylaxis in hospitalized medical patients: a meta-analysis of randomized controlled trials. Arch Intern Med 2007;167:1476-86.

72. Barbar S, Noventa F, Rossetto V, et al. A risk assessment model for the identification of hospitalized medical patients at risk for venous thromboembolism: the Padua Prediction Score. J Thromb Haemost 2010;8:2450-7.

73. Caprini JA. Thrombosis risk assessment as a guide to quality patient care. Dis Mon 2005;51:70-8.

74. Venous Thromboembolism: Reducing the Risk of Venous Thromboembolism (Deep Vein Thrombosis and Pulmonary Embolism) in Patients Admitted to Hospital. London: Royal College of Physicians (UK), 2010.

75. Spyropoulos AC, Anderson FA, FitzGerald G, et al. Predictive and associative models to identify hospitalized medical patients at risk for VTE. Chest 2011;140:706-14.

76. Chi G, Lee JJ, Jamil A, et al. Venous Thromboembolism among Hospitalized Patients with COVID-19 Undergoing Thromboprophylaxis: A Systematic Review and MetaAnalysis. J Clin Med 2020;9:E2489.

77. Wang T, Chen R, Liu C, et al. Attention should be paid to venous thromboembolism prophylaxis in the management of COVID-19. Lancet Haematol 2020;7:e362-3.

78. Tang N, Bai H, Chen X, et al. Anticoagulant treatment is associated with decreased mortality in severe coronavirus disease 2019 patients with coagulopathy. J Thromb Haemost 2020;18:1094-9.

79. Thachil J, Tang N, Gando S, et al. ISTH interim guidance on recognition and management of coagulopathy in COVID-19. J Thromb Haemost 2020;18:1023-6.

80. Clinical management of severe acute respiratory infection when COVID-19 is suspected. Available online: https:// www.who.int/publications-detail/clinical-managementof-severe-acute-respiratory-infection-when-novelcoronavirus-(ncov)-infection-is-suspected, 2020 (consultada el 10 de mayo de 2020).

81. COVID-19 and VTE-Anticoagulation - Hematology. org. Available online: https://www.hematology.org:443/ covid-19/covid-19-and-vte-anticoagulation 2020 (consultada el 10 de mayo de 2020).

82. Hunt B, Retter A, McClintock C. Practical guidance for the prevention of thrombosis and management of coagulopathy and disseminated intravascular coagulation of patients infected with COVID-19. Available online: https://thrombosisuk.org/covid-19-thrombosis.php, 2020 (consultada el 10 de mayo de 2020).

83. Vivas D, Roldán V, Esteve-Pastor MA, et al.

Recommendations on antithrombotic treatment during the COVID-19 pandemic. Position statement of the Working Group on Cardiovascular Thrombosis of the Spanish Society of Cardiology. Rev Esp Cardiol 2020;73:749-57.

84. Sociedad Española de Trombosis y Hemostasia.

Recomendaciones de tromboprofilaxis y tratamiento antitrombótico en pacientes con COVID-19. Available online: https://www.covid-19.seth.es/recomendacionesde-tromboprofilaxis-y-tratamiento-antitrombotico-enpacientes-con-covid-19/, 2020 (consultada el 10 de mayo de 2020).

85. BTS guidance on venous thromboembolic disease in patients with COVID-19 (updated 4 May 2020), Available online: https://brit-thoracic.org.uk/document-library/ quality-improvement/covid-19/bts-guidance-on-venousthromboembolic-disease-in-patients-with-covid-19/, 2020.

86. Paar V, Jirak P, Gruber S, et al. Influence of dabigatran on pro-inflammatory cytokines, growth factors and chemokines - Slowing the vicious circle of coagulation and inflammation. Life Sci 2020;262:118474.

87. Hanify JM, Dupree LH, Johnson DW, et al. Failure of chemical thromboprophylaxis in critically ill medical and surgical patients with sepsis. J Crit Care 2017;37:206-10.

88. Dahan R, Houlbert D, Caulin C, et al. Prevention of deep vein thrombosis in elderly medical in-patients by a low molecular weight heparin: a randomized double-blind trial. Haemostasis 1986;16:159-64.

89. Fraisse F, Holzapfel L, Couland JM, et al. Nadroparin in the prevention of deep vein thrombosis in acute decompensated COPD. The Association of NonUniversity Affiliated Intensive Care Specialist Physicians of France. Am J Respir Crit Care Med 2000;161:1109-14. 
90. Ikesaka R, Delluc A, Le Gal G, et al. Efficacy and safety of weight-adjusted heparin prophylaxis for the prevention of acute venous thromboembolism among obese patients undergoing bariatric surgery: a systematic review and meta-analysis. Thromb Res 2014;133:682-7.

91. Marietta M, Ageno W, Artoni A, et al. COVID-19 and haemostasis:a position paper from Italian Society on Thrombosis and Haemostasis (SISET). Blood Transfus 2020;18:167-9.

92. Liew AYL, Piran S, Eikelboom JW, et al. Extendedduration versus short-duration pharmacological thromboprophylaxis in acutely Ill hospitalized medical patients: a systematic review and meta-analysis of randomized controlled trials. J Thromb Thrombolysis 2017;43:291-301.

93. Moores LK, Tritschler T, Brosnahan S, et al. Prevention, diagnosis and treatment of venous thromboembolism in patients with COVID-19: CHEST Guideline and Expert Panel Report. Chest 2020;158:1143-63.

94. Ho KM, Tan JA. Stratified meta-analysis of intermittent pneumatic compression of the lower limbs to prevent

Cite this article as: García-Ortega A, de la Rosa D, Oscullo G, Castillo-Villegas D, López-Reyes R, Martínez-García MÁ. Coagulation disorders and thromboembolic disease in COVID-19: review of current evidence in search of a better approach. J Thorac Dis 2021;13(2):1239-1255. doi: 10.21037/ jtd-20-3062 venous thromboembolism in hospitalized patients. Circulation 2013;128:1003-20.

95. Bikdeli B, Lobo JL, Jiménez D, et al. Early Use of Echocardiography in Patients With Acute Pulmonary Embolism: Findings From the RIETE Registry. J Am Heart Assoc 2018;7:e009042.

96. Thachil J. The versatile heparin in COVID-19. J Thromb Haemost 2020;18:1020-2.

97. Kahn SR, Lim W, Dunn AS, et al. Prevention of VTE in nonsurgical patients: Antithrombotic Therapy and Prevention of Thrombosis, 9th ed: American College of Chest Physicians Evidence-Based Clinical Practice Guidelines. Chest 2012;141:e195S-e226S.

98. Whyte MB, Kelly PA, Gonzalez E, et al. Pulmonary embolism in hospitalised patients with COVID-19. Thromb Res 2020;195:95-9.

99. van Dam LF, Kroft LJM, van der Wal LI, et al. Clinical and computed tomography characteristics of COVID-19 associated acute pulmonary embolism: A different phenotype of thrombotic disease? Thromb Res 2020;193:86-89. 